\title{
Child vaccination at the Outpatient Clinic of the Pro Medica Center in Bialystok, Poland, in the years 2013-2016
}

\author{
JOLANTA KRAŚNICKA ${ }^{1, A-F}$, ELŻBIETA KRAJEWSKA-KUŁAK ${ }^{2, A, D, E, G}, K^{2}$ RYSTYNA KLIMASZEWSKA ${ }^{2, D, F}$, \\ MATEUSZ CYBULSKI ${ }^{2, D} \mathrm{D}, \mathrm{F}$, ANDRZEJ GUZOWSKI ${ }^{2, D, F}$, ANNA BARANOWSKA ${ }^{2, D, F}$, \\ AGNIESZKA LANKAU ${ }^{2, D, F}$, AGNIESZKA SZYSZKO-PER $Ł O W S K A^{2, D, F}$, DOROTA KONDZIOR ${ }^{2, D, F}$, \\ HALINA DOROSZKIEWICZ ${ }^{3, F}$, PALLAV SENGUPTA ${ }^{4, A, F}$, WOJCIECH KUŁAK ${ }^{5, A, F}$
}

\author{
${ }^{1}$ Family Doctors Clinic "Pro Medica Centrum", Bialystok, Poland \\ ${ }^{2}$ Department of Integrated Medical Care, Medical University of Bialystok, Poland \\ ${ }^{3}$ Department of Geriatrics, Medical University of Bialystok, Poland \\ ${ }^{4}$ Department of Physiology, Faculty of Medicine, MAHSA University, Malaysia \\ ${ }^{5}$ Department of Pediatric Rehabilitation, Medical University of Bialystok, Poland
}

A - Study Design, B - Data Collection, C - Statistical Analysis, D - Data Interpretation, E - Manuscript Preparation, F - Literature Search, G - Funds Collection

Summary Background. The number of parents refusing to vaccinate their children has been increasing year by year. Objectives. The aim of the study was to analyze child vaccination at the Outpatient Clinic of the Pro Medica Center in Bialystok, Poland, in the years 2013-2016.

Material and methods. A total of 10,150 histories of children and adolescents were analyzed. We analyzed the following data: number of children and adolescents vaccinated in 2013-2016; type of vaccination; reimbursed and polyvalent vaccines; vaccinations against tuberculosis; occurrence of contraindications to vaccination; number contraindications to vaccination, and number of vaccinations recommended in the particular years.

Results. $48.8 \%$ of the children were vaccinated with refunded vaccines. $18.3 \%$ of children were not vaccinated in $2016.60 .3 \%$ were BCG-vaccinated. There was an increased number of contraindications for vaccination from 2013 to 2016, mainly in children aged 2, 6 , 7 , and 10 years. In 2016, the number of vaccinations against rotaviruses decreased, and the number of vaccinations increased against meningococcus and tick-borne inflammation. There was a statistically significant decrease in vaccination against diphtheria and tetanus from Haemophilus influenzae B, pertussis, poliomyelitis; and measles, mumps, and rubella, from 2013 to 2016.

Conclusions. In the years 2013-2016, there was an increase in the incidence of contraindications for protective vaccinations, a decrease in the number of vaccinations against rotaviruses, and an increase in the number of vaccinations against meningococcal meningitis and tick-borne encephalitis.

Key words: vaccination, child, ambulatory care facilities.

Kraśnicka J, Krajewska-Kułak E, Klimaszewska K, Cybulski M, Guzowski A, Baranowska A, Lankau A, Szyszko-Perłowska A, Kondzior D, Doroszkiewicz H, Sengupta P, Kułak W. Child vaccination at the Outpatient Clinic of the Pro Medica Center in Bialystok, Poland, in the years 2013-2016. Fam Med Prim Care Rev 2018; 20(4): 341-345, doi: https://doi.org/10.5114/fmpcr.2018.79345.

\section{Background}

Opposition to vaccines is not a new event and appeared soon after the introduction of the smallpox vaccine in the late $18^{\text {th }}$ century. The beliefs and arguments of the anti-vaccine movement have remained unchanged over the past two centuries, but new social media has facilitated the dissemination of information against vaccines [1].

The determinants of vaccine refusal are complex. There are several sociocultural, political, and personal factors. Doubts concerning the actual need for vaccines, vaccine safety, fear of possible adverse events, possible immune system overexposure, and past negative experiences with vaccines are also factors for refusal of vaccination [2,3].

Despite being recognized as one of the most successful public health measures, vaccination is perceived as unsafe and unnecessary by a growing number of parents. Anti-vaccination movements have been implicated in lowered vaccine acceptance rates and in the increase in vaccine-preventable disease outbreaks and epidemics $[4,5]$.
With little or no evidence-based information to back up claims of vaccine danger, anti-vaccine activists have relied on the power of storytelling to infect an entire generation of parents with fear of and doubt about vaccines. These parental accounts of perceived vaccine injury, coupled with Andrew Wakefield's fraudulent research study linking the MMR vaccine to autism, created a substantial amount of vaccine hesitancy in new parents, which manifests in both vaccine refusal and the adoption of delayed vaccine schedules [6].

For over 200 years of vaccination in the world, many dangerous infectious diseases have been eliminated, or their number has been significantly reduced. After introducing vaccinations, the decrease in deaths from infectious diseases fell from $20-25 \%$ (first half of the $20^{\text {th }}$ century) to below $1 \%$ [7].

All vaccinations in children in Poland are implemented in accordance with the vaccination schedule, which contains information about mandatory and recommended vaccinations. In Poland, in addition to free-of-charge vaccines, listed in the national program on immunization, self-paid vaccinations for pneumococcal, meningococcal, rotavirus, varicella, influenza 
infections, and combination vaccines are recommended. The schedule of vaccinations in Poland is subject to annual amendment, depending on the changing epidemiological situation, health threats, the level of immunization, mainly of children and adolescents, based on the state of vaccination and the obtained results. The set of vaccinations to be used in Poland does not differ significantly from those in force in other European Union countries [8].

The value of preventive vaccination as one of the methods of protection against infectious diseases is undeniable, which is worth emphasizing in the context of the growing number of refusals to perform vaccinations among children and adolescents. The implementation of obligatory vaccinations in Poland was and is generally high and very high, reaching over $90 \%$ of people subject to vaccination (in many cases, above 95\%), and in some provinces, this reaches values close to $100 \%$ [7]. The data of the National Institute of Hygiene in Poland shows that the number of vaccination refusals has increased significantly in recent years [9]. In 2010, there were 3,437 refusals, 4,689 in 2011, 5,340 in $2012,7,248$ in 2013, 12,681 in 2014, 16,689 in 2015, 23,147 in 2016, and 30,089 in 2017.

\section{Objectives}

The aim of this study was to analyze the vaccination rate of children and adolescents at the Outpatient Clinic of Pro Medica Center in Bialystok, Poland, in the years 2013-2016.

\section{Material and methods}

The research was carried out from July 2015 to June 2016, after obtaining the consent of the Bioethics Committee of the Medical University of Bialystok R-I-002/196/2015 and the consent of the Directorate of the Pro Medica Family Medicine Center in Bialystok, Poland.

We analyzed 10,150 histories of children and adolescents (primary care files). We analyzed the following data: number of children and adolescents under the care of the Pro Medica Family Medicine Center in Bialystok in 2013-2016; frequency of use among children up to two years of age and type of vaccination; use in children of reimbursed and highly-associated vaccines; vaccinations against tuberculosis; occurrence of contraindications to vaccination; number of contraindications to vaccination in relation to years and the age of children; number of vaccinations recommended in the particular years.

Children and adolescents were vaccinated at the Pro Medica Family Medicine Center in Bialystok according to the vaccination calendar valid in Poland [9].

The results are presented as mean values \pm SD. Non-parametric tests, chi-square and Fisher's exact test were applied to compare differences in time. The critical level of significance for all tests was $p<0.05$.

\begin{tabular}{|c|c|c|c|c|}
\hline \multirow[t]{2}{*}{ Age (year) } & \multicolumn{4}{|c|}{ Calendar year } \\
\hline & 2013 & 2014 & 2015 & 2016 \\
\hline 1 & 59 & 67 & 57 & 60 \\
\hline 2 & 74 & 64 & 67 & 62 \\
\hline 3 & 68 & 76 & 60 & 59 \\
\hline 4 & 62 & 75 & 72 & 65 \\
\hline 5 & 77 & 62 & 72 & 70 \\
\hline 6 & 78 & 79 & 58 & 69 \\
\hline 7 & 46 & 73 & 83 & 57 \\
\hline 8 & 48 & 47 & 75 & 82 \\
\hline
\end{tabular}

\begin{tabular}{|l|l|l|l|l|}
\hline 9 & 62 & 49 & 46 & 74 \\
\hline 10 & 63 & 59 & 46 & 46 \\
\hline 11 & 58 & 63 & 55 & 44 \\
\hline 12 & 61 & 63 & 61 & 57 \\
\hline 13 & 67 & 59 & 61 & 60 \\
\hline 14 & 56 & 64 & 60 & 59 \\
\hline 15 & 63 & 54 & 66 & 59 \\
\hline 16 & 71 & 63 & 52 & 60 \\
\hline 17 & 70 & 72 & 62 & 54 \\
\hline 18 & 56 & 72 & 70 & 60 \\
\hline 19 & 77 & 57 & 73 & 69 \\
\hline 20 & 79 & 75 & 55 & 70 \\
\hline Total & $\mathbf{1 , 2 9 5}$ & $\mathbf{1 , 2 9 3}$ & $\mathbf{1 , 2 5 1}$ & $\mathbf{1 , 2 3 6}$ \\
\hline
\end{tabular}

Table 1 summarizes the number of children under primary care in 2013-2016. We noted slight fluctuations in the number of patients resulting from changes in clinics or a move to another town. For example, in 2013, 62 4-year-old children were registered in the clinic; in the following year, their number was still 62 people; in the next two years, this cohort was reduced to 58 in 2015 and 57 in 2016.

\section{Results}

Table 2 shows the frequency of application of combined vaccines among children up to two years in the years 2013-2016. The statistical significance of the percentage distribution of combined vaccination frequency was evaluated using the chi-square independence test. The distribution of results of vaccination rate differed significantly between the years $(p=0.008)$. It seems that the impact was due to some children not receiving vaccinations in 2016 . Nearly half $(48.8 \%)$ of the children were immunized with refunded vaccinations, and $44 \%$ were vaccinated with combined vaccines. The highest number $(18.3 \%)$ of unvaccinated children occurred in 2016.

A second analysis concerning the frequency of refunded and combined vaccine use among children up to two years in 2013-2016 (Table 3) was made. After removing unvaccinated children from the analysis, no significant differences in the frequency of combined vaccines (paid by the children's parents) were found.

\begin{tabular}{|c|c|c|c|c|}
\hline \multirow[t]{2}{*}{ Year } & \multicolumn{3}{|c|}{ Type of vaccination $(p=0.008 * *)$} & \multirow[t]{2}{*}{ Total } \\
\hline & Refunded & Polyvalent & $\begin{array}{l}\text { No } \\
\text { vaccination }\end{array}$ & \\
\hline 2013 & $30(50.0 \%)$ & $28(46.7 \%)$ & $2(3.3 \%)$ & 60 \\
\hline 2014 & $34(48.6 \%)$ & $35(50.0 \%)$ & $1(1.4 \%)$ & 70 \\
\hline 2015 & $34(54.8 \%)$ & $24(38.7 \%)$ & $4(6.5 \%)$ & 62 \\
\hline 2016 & $25(41.7 \%)$ & $24(40.0 \%)$ & $11(18.3 \%)$ & 60 \\
\hline Total & $123(48.8 \%)$ & $111(44.0 \%)$ & $18(4.2 \%)$ & 252 \\
\hline
\end{tabular}

$p$ - test probability value calculated using the chi-square independence test.

In total, 60.3 children were vaccinated against tuberculosis according to the immunization schedule. A delay in vaccinating up to the $14^{\text {th }}$ day of life concerned $38 \%$ of children, including the highest in 2014 (56.5\%). Children with a delay after 14 days of age amounted $1.7 \%$ of the total, including no cases in 2014 and 2016. The details are presented in Table 4.

The next part of the analysis concerned comparing the number of children who had contraindications to vaccination. Table 5 shows the contraindications to vaccination. 


\begin{tabular}{|c|c|c|c|}
\hline \multirow{3}{*}{ Year } & \multirow{2}{*}{\multicolumn{2}{|c|}{ Type of vaccination $(p=0.7492)$}} & \multirow{3}{*}{ Total } \\
\hline & & & \\
\hline & Refunded & Polyvalent & \\
\hline 2013 & $30(51.7 \%)$ & $28(48.3 \%)$ & 58 \\
\hline 2014 & 34 (49.3\%) & 35 (50.7\%) & 69 \\
\hline 2015 & $34(58.6 \%)$ & $24(41.4 \%)$ & 58 \\
\hline 2016 & $25(51.0 \%)$ & 24 (49.0\%) & 49 \\
\hline Total & $123(52.6 \%)$ & $111(47.4 \%)$ & 234 \\
\hline
\end{tabular}

$p$ - test probability value calculated using the chi-square independence test.

\begin{tabular}{|c|c|c|c|c|c|}
\hline \multirow[t]{2}{*}{ Year } & \multicolumn{4}{|c|}{$\begin{array}{l}\text { Vaccination against tuberculosis } \\
(p<0.001 * *)\end{array}$} & \multirow[t]{2}{*}{ Total } \\
\hline & $\begin{array}{l}\text { number of } \\
\text { vaccinated } \\
\text { newborns }\end{array}$ & \multicolumn{2}{|c|}{$\begin{array}{l}\text { with delay } \\
\text { (up to } 14 \\
\text { days old) }\end{array}$} & $\begin{array}{l}\text { with delay } \\
\text { (after } 14 \\
\text { days of life) }\end{array}$ & \\
\hline 2013 & $46(31.5 \%)$ & \multicolumn{2}{|c|}{11 (12.0\%) } & $2(50.0 \%)$ & 59 \\
\hline 2014 & 15 (10.3\%) & \multicolumn{2}{|c|}{52 (56.5\%) } & $0(0.0 \%)$ & 67 \\
\hline 2015 & 38 (26.0\%) & \multicolumn{2}{|c|}{$16(17.4 \%)$} & 2 (50.0\%) & 56 \\
\hline 2016 & 47 (32.2\%) & \multicolumn{2}{|c|}{$13(14.1 \%)$} & $0(0.0 \%)$ & 60 \\
\hline Total & 146 (60.3\%) & \multicolumn{2}{|c|}{92 (38\%) } & 4 (1.7\%) & 242 \\
\hline \multirow[t]{2}{*}{ Year } & \multicolumn{4}{|c|}{$\begin{array}{l}\text { Vaccination against tuberculosis } \\
(p<0.001 * *)\end{array}$} & Total \\
\hline & \multicolumn{2}{|c|}{$\begin{array}{l}\text { number of vacci- } \\
\text { nated newborns }\end{array}$} & \multicolumn{2}{|c|}{ with delay } & \\
\hline 2013 & \multicolumn{2}{|l|}{46 (31.5\%) } & \multicolumn{2}{|c|}{$13(13.5 \%)$} & 59 \\
\hline 2014 & \multicolumn{2}{|l|}{15 (10.3\%) } & \multicolumn{2}{|c|}{52 (54.2\%) } & 67 \\
\hline 2015 & \multicolumn{2}{|l|}{$38(26.0 \%)$} & \multicolumn{2}{|c|}{$18(18.8 \%)$} & 56 \\
\hline 2016 & \multicolumn{2}{|l|}{$47(32.2 \%)$} & \multicolumn{2}{|c|}{$13(13.5 \%)$} & 60 \\
\hline Total & \multicolumn{2}{|l|}{146 (60.3\%) } & \multicolumn{2}{|c|}{96 (39.7\%) } & 242 \\
\hline
\end{tabular}

$p$ - test probability value calculated using the chi-square independence test.

Significant differences were found in the presence of contraindications from the respiratory system and, in general, all contraindications. Table 5 also lists the number and incidence of contraindications to vaccination in relation to the analyzed years and the children's age. Contraindications to vaccination appeared mainly at age 2, 6, 7, and 10 years of age, which is probably related to the calendar of preventive vaccinations. The details are provided in Table 6 .

In the next part of the research, information on the number and percentage frequency of vaccinations recommended in particular years was summarized. Table 7 shows the number and percentage of recommended vaccinations in 2013. In the group of children in the first year of life in 2016, the number of vaccinations against rotavirus decreased. Furthermore, we found a significant increase in vaccinations against meningococcal meningitis and tick-borne encephalitis. The details are presented in Table 7.

We found significant gaps in vaccination against diphtheria and tetanus from 92 in 2013 to 162 cases in 2016 (< 0.001); whooping cough - from 42 in 2013 to 97 in 2016 (0.0184); poliomyelitis - from 47 in 2013 to 97 in 2016 (0.0231); measles, mumps, rubella - from 63 in 2013 to 97 in 2016 (0.0141); Haemophilus influenzae B - from 14 in 2013 to 34 in 2016. The details are presented in Table 8.

\begin{tabular}{|c|c|c|c|c|c|}
\hline \multirow{3}{*}{$\begin{array}{l}\text { Occurrence of } \\
\text { contraindica- } \\
\text { tions to vac- } \\
\text { cination }\end{array}$} & \multicolumn{4}{|l|}{ Year } & \multirow[t]{3}{*}{$p$} \\
\hline & 2013 & 2014 & 2015 & 2016 & \\
\hline & $n$ & $n$ & $n$ & $n$ & \\
\hline \multicolumn{6}{|c|}{ On the part of the system } \\
\hline Nervous & 5 & 5 & 5 & 9 & 0.5193 \\
\hline Respiratory & 8 & 2 & 22 & 44 & $<0.001^{* * *}$ \\
\hline Urinary & 0 & 0 & 1 & 0 & $0.4900^{11}$ \\
\hline Circulatory & 0 & 0 & 0 & 0 & 1.0000 \\
\hline Food & 0 & 0 & 0 & 0 & 1.0000 \\
\hline \multicolumn{6}{|c|}{ Because of illness } \\
\hline Allergic & 1 & 0 & 0 & 0 & $1.0000^{1)}$ \\
\hline Rheumatic & 0 & 0 & 0 & 0 & 1.0000 \\
\hline Blood & 0 & 2 & 1 & 2 & $0.4976^{1)}$ \\
\hline Birth Defect & 0 & 0 & 0 & 0 & 1.0000 \\
\hline Another & 0 & 1 & 1 & 0 & $0.7441^{1)}$ \\
\hline \multicolumn{6}{|l|}{ For any reason } \\
\hline Total & 14 & 10 & 30 & 55 & $0.0000 * * *$ \\
\hline
\end{tabular}

${ }^{1)}$ The significance of the differences was assessed using the Fisher's exact test.

\begin{tabular}{|c|c|c|c|c|c|}
\hline \multirow[t]{3}{*}{ Age (year) } & \multicolumn{4}{|l|}{ Year } & \multirow[t]{3}{*}{$p$} \\
\hline & 2013 & 2014 & 2015 & 2016 & \\
\hline & $n$ & $n$ & $n$ & $n$ & \\
\hline 1 & 1 & 0 & 0 & 0 & $0.4774^{1)}$ \\
\hline 2 & 1 & 2 & 12 & 17 & $<0.001 * * *$ \\
\hline 3 & 1 & 3 & 2 & 1 & $0.8103^{1)}$ \\
\hline 4 & 0 & 0 & 3 & 3 & $0.1097^{11}$ \\
\hline 5 & 0 & 0 & 0 & 1 & $0.4698^{11}$ \\
\hline 6 & 1 & 1 & 3 & 16 & $<0.001 * * *$ \\
\hline 7 & 0 & 0 & 6 & 0 & $0.0046^{* *}$ \\
\hline 8 & 0 & 0 & 0 & 3 & $0.0719^{1)}$ \\
\hline 9 & 0 & 0 & 0 & 0 & 1.0000 \\
\hline 10 & 4 & 0 & 0 & 8 & $0.0004^{* * *}$ \\
\hline 11 & 3 & 1 & 1 & 0 & $0.3369^{11}$ \\
\hline 12 & 1 & 1 & 1 & 0 & $1.0000^{1)}$ \\
\hline 13 & 0 & 1 & 1 & 1 & $0.7084^{1)}$ \\
\hline 14 & 2 & 0 & 1 & 3 & $0.2338^{1)}$ \\
\hline 15 & 0 & 0 & 0 & 1 & $0.4669^{1)}$ \\
\hline 16 & 0 & 1 & 0 & 0 & $0.7114^{1)}$ \\
\hline 17 & 0 & 0 & 0 & 0 & 1.0000 \\
\hline 18 & 0 & 0 & 0 & 0 & 1.0000 \\
\hline 19 & 0 & 0 & 0 & 1 & $0.4565^{1)}$ \\
\hline
\end{tabular}

${ }^{1)}$ The significance of the differences was assessed using the Fisher's exact test.

\begin{tabular}{|c|c|c|c|c|c|}
\hline \multirow{3}{*}{$\begin{array}{l}\text { Recommended } \\
\text { vaccines }\end{array}$} & \multicolumn{4}{|l|}{ Year } & \multirow[t]{3}{*}{$p$} \\
\hline & 2013 & 2014 & 2015 & 2016 & \\
\hline & $n$ & $n$ & $n$ & $n$ & \\
\hline Rotavirus & 17 & 16 & 22 & 10 & 0.0549 \\
\hline Pneumococci & 31 & 25 & 24 & 24 & 0.6696 \\
\hline Chickenpox & 1 & 1 & 4 & 2 & 0.3688 \\
\hline Meningococcus & 3 & 4 & 9 & 12 & $0.0384 *$ \\
\hline Tick brain disease & 7 & 5 & 10 & 17 & $0.0251 *$ \\
\hline Whooping cough & 1 & 0 & 0 & 0 & 0.4042 \\
\hline Hepatitis A & 0 & 1 & 0 & 0 & 0.4033 \\
\hline Flu & 9 & 7 & 6 & 4 & 0.6239 \\
\hline
\end{tabular}

$p$ - test probability value calculated using the chi-square independence test. 


\begin{tabular}{|l|l|l|l|l|l|}
\hline \multirow{6}{*}{$\begin{array}{l}\text { Table 8. No mandatory vaccination in particular years } \\
\text { No mandatory }\end{array}$} & \multicolumn{4}{|l|}{ Year } & \multicolumn{4}{l|}{} \\
\cline { 2 - 6 } & 2013 & 2014 & 2015 & 2016 & \\
\cline { 2 - 6 } & $n$ & $n$ & $n$ & $n$ & \\
\hline Hepatitis B & 7 & 8 & 11 & 15 & 0.1827 \\
\hline $\begin{array}{l}\text { Diphtheria, } \\
\text { tetanus }\end{array}$ & 92 & 117 & 143 & 162 & $<0.001^{* * *}$ \\
\hline Whooping cough & 42 & 56 & 63 & 97 & $0.0184^{*}$ \\
\hline Poliomyelitis & 47 & 57 & 63 & 79 & $0.0231^{*}$ \\
\hline $\begin{array}{l}\text { Measles. mumps. } \\
\text { rubella }\end{array}$ & 63 & 73 & 81 & 97 & $0.0141^{*}$ \\
\hline Rubella & 20 & 19 & 20 & 21 & 0.9976 \\
\hline $\begin{array}{l}\text { Haemophilus } \\
\text { influenzae B }\end{array}$ & 14 & 20 & 22 & 34 & $0.0066^{* *}$ \\
\hline Tuberculosis & 15 & 18 & 19 & 19 & 0.8385 \\
\hline
\end{tabular}

$p$ - test probability value calculated using the chi-square independence test.

\section{Discussion}

In the present study, we found an increase of unvaccinated children and also noted an increasing tendency in the incidence of contraindications to vaccinations. Only $4.2 \%$ of the children and adolescents were unvaccinated. Our findings are in accordance with previous reports [10-14].

Hoffmann et al. [10] analyzed documentation from 2005-2007 of a population of 1,875 patients aged $0-19$ years old in Pleszew. The rate of vaccination was high and very high and ranged between 95 and $100 \%$. In the study by Lipska et al. [11], $44 \%$ of the surveyed parents gave their children at least one of the recommended vaccinations, while as many as $56 \%$ did not use any of these vaccinations. A study in a group of 977 person-representative random samples of adult Polish residents showed that only $3 \%$ of adult Poles with children claim that their child (children) has not been subjected to vaccination against infectious disease at least once [12]. In the current study, only $4.2 \%$ of the children and adolescents were unvaccinated.

Gawłowska-Lichota and Płatek [13] analyzed the immunization of children and adolescents in 2004-2008 at the Health Care Center in Polanow. The study involved 2,302 students aged 10-19 to be immunized in 2004-2008. The percentage of vaccinated students was $100 \%$ in the years $2004-2005$, and $97 \%$ in 2007

In the current study, $48.8 \%$ were vaccinated with refunded vaccines. The highest rate (54.8\%) was in 2015, and the lowest $(41.7 \%)$ in 2016 . Nearly half (44\%) of the children were vaccinated with combined vaccines; the highest (50\%) percentage was in 2014, and the lowest (40\%) in 2016.

In a study from 2008 [13], immunization against measles, rubella, and mumps totaled 100\% in 2005 and 2006. Similarly, in the current study, almost all children were vaccinated against measles, rubella, and mumps in the years 2013-2016.

According to Smith et al. [14], in order to prevent a measles outbreak in a given environment, vaccination against MMR is required at a level of at least $95 \%$. The above was confirmed by Nagaraja's research, which showed that in countries where the use of this vaccine fell to about $50 \%$, there was an increase in complications arising from measles and death [15]. In the current study, vaccinations against measles, mumps, and rubella increased from year to year.

In the group of children from the Lipska et al. [11] study, who received additional vaccinations, most (73.32\%) were vaccinated against pneumococci. Less frequently, $21 \%$ of cases were vaccinated against influenza, $14 \%$ against rotaviruses, and $12 \%$ against meningococcus. Similar results were noted in the present study.

The number of parents refusing to vaccinate their children has been increasing year by year. In a CBOS report, $40 \%$ of adults declared refusing vaccinations due to the side effects of the vaccine, and $39 \%$ due to medical contraindications (39\%) [12].

In the present study, contraindications for vaccination mainly appeared at age $2,6,7$, and 10 years of age, which led to an increasing tendency in the share of children whose vaccination was not performed in a timely manner.

It should be emphasized here that immunization programs are designed in such a way as to protect not only vaccinated people from falling ill, but also those unvaccinated by creating so-called population resistance.

To reduce number of unvaccinated children, the American Academy of Pediatrics, in the statement "Responding to Parental Refusals of Immunization in Children" published in 2005 [16], recommends that pediatricians should: 1) listen carefully and respectfully to the parent's concerns, (2) share honestly what is and is not known about the risks and benefits of the vaccine in question, (3) attempt to correct any misperceptions and misinterpretations, (4) assist parents in understanding that the risks of any vaccine should not be considered in isolation but in comparison to the risks of remaining unimmunized, (5) discuss concerns about each vaccine separately, (6) explore the possibility that cost is a reason for refusal, (7) respect and document every refusal.

These recommendations may also be applicable in Poland.

\section{Conclusions}

1. In the years 2013-2016, an increase in unvaccinated children was found.

2. We have found no changes in the frequency of use of combined vaccines.

3. We noted an increasing tendency in the incidence of contraindications to vaccinations.

4. Family doctors should assist parents more in education on the benefits of vaccination.

5. Family physicians should spend more time with parents refusing vaccinations to explain the real risk of vaccinations and the lack of vaccination of their children.

Source of funding: This work was funded by the authors' own resources. Conflicts of interest: The authors declare no conflicts of interest.

\section{References}

1. Succi RCM. Vaccine refusal - what we need to know. J Pediatr (Rio J) 2018: 94(6): 574-581, doi: 10.1016/j.jped.2018.01.008.

2. MacDonald NE. SAGE Working Group on Vaccine Hesitancy. Vaccine hesitancy: definition, scope and determinants. Vaccine 2015: 33(34): 4161-4164.

3. McClure CC, Cataldi JR, O'Leary ST. Vaccine hesitancy: where we are and where we are going. Clin Ther 2017; 39(8): $1550-1562$.

4. Dubé E, Vivion M, MacDonald NE. Vaccine hesitancy, vaccine refusal and the anti-vaccine movement: influence, impact and implications. Expert Rev Vaccines 2015: 14(1): 99-117.

5. Kata A. Anti-vaccine activists, Web 2.0, and the postmodern paradigm - an overview of tactics and tropes used online by the antivaccination movement. Vaccine 2012; 30(25): 3778-3789. 
6. Shelby A, Ernst K. Story and science: how providers and parents can utilize storytelling to combat anti-vaccine misinformation. Hum Vaccin Immunother 2013: 9(8): 1795-1801.

7. Magdzik W. Historia uodpornienia sztucznego. In: Magdzik W, Naruszewicz-Lesiuk D, Zieliński A, eds. Wakcynologia. Bielsko Biała: $\alpha$-medica Press; 2007: 58-62 (in Polish).

8. Zgliczyński WS, Cianciara D. Szczepienia ochronne dzieci i młodzieży w Polsce - wybrane zagadnienia. Analizy 2015; 2(122): 1-10 (in Polish).

9. Odmowy szczepień [cited 24.02.2017]. Available from URL: http://szczepienia.pzh.gov.pl/ (in Polish).

10. Hoffmann L, Sapilak BJ, Hans-Wytrychowska A, et al. Szczepienia ochronne obowiązkowe i zalecane w praktyce lekarza rodzinnego NZOZ „Zdrowie” w Pleszewie obejmujące populację dzieci i młodzieży do 19. r.ż. - analiza wszczepialności i próba oceny czynników wpływających na jej wzrost. Fam Med Prim Care Rev 2009; 11(3): 337-340 (in Polish).

11. Lipska E, Lewińska M, Górnicka G. Realizacja szczepień zalecanych u dzieci i opinie rodziców na temat tych szczepień. Nowa Med 2013; 2: 64-69 (in Polish).

12. Gwiazda M. Polacy o obowiązku szczepienia dzieci. Komunikat z badań CBOS 2017; 100: 1-13 (in Polish).

13. Gawłowska-Lichota K, Płatek M. Analiza wyszczepialności dzieci wybranymi szczepionkami na terenie Zakładu Opieki Zdrowotnej w Polanowie w latach 2004-2008. Probl Pielęg 2011; 19(1): 34-38 (in Polish).

14. Smith A, Yarwood J, Salisbury DM. Tracking mothers' attitudes to MMR immunization 1996-2006. Vaccine 2007; 25: $3996-4002$.

15. Nagaraj A. Does qualitative synthesis of anecdotal evidence with that from scientific research help in understanding public health issues: a review of low MMR uptake. Eur J Public Health 2006; 16(1): 85-88.

16. Diekema DS. American Academy of Pediatrics Committee on Bioethics. Responding to parental refusals of immunization of children. Pediatrics 2005: 115(5): 1428-1431.

Tables: 8

Figures: 0

References: 16

Received: 17.04 .2018

Reviewed: 27.04.2018

Accepted: 09.05.2018

Address for correspondence:

Prof. Elżbieta Krajewska-Kułak

Zakład Zintegrowanej Opieki Medycznej UM

ul. Marii Skłodowskiej-Curie 7A

15-096 Białystok

Polska

Tel.: +48 85 748-55-28

E-mail: elzbieta.krajewska@wp.pl 